\section{Effects of Salicylic Acid and Calcium Chloride on Heat Tolerance of Poinsettia}

\author{
Kuan-Hung Lin \\ Faculty of Applied Sciences, Ton Duc Thang University, Ho Chi Minh City \\ 700000, Vietnam, Department of Horticulture and Biotechnology, Chinese \\ Culture University, Taipei 111, Taiwan
}

\author{
Shao-Bo Huang \\ Department of Horticulture and Landscape Architecture, National Taiwan \\ University, Taipei 106, Taiwan
}

Chun-Wei Wu ${ }^{1}$

Center for General Education, Kang Ning University, Taipei 114, Taiwan

\author{
Yu-Sen Chang ${ }^{1}$ \\ Department of Horticulture and Landscape Architecture, National Taiwan \\ University, Taipei 106, Taiwan
}

Additional index words. calcium chloride, poinsettia, relative injury, salicylic acid

\begin{abstract}
Exogenous application of either salicylic acid (SA) or calcium chloride $\left(\mathrm{CaCl}_{2}\right)$ to alleviate heat stress has been extensively studied. However, the effects of combined $\mathrm{SA}$ and $\mathrm{CaCl}_{2}$ treatment on the heat tolerance of poinsettia have been poorly studied. This study investigated the role of a foliar spray comprising $\mathbf{S A}$ and $\mathbf{C a C l}_{2}$ in managing heat tolerance of three poinsettia (Euphorbia pulcherrima Willd.) cultivars, Noel, Winter Rose (WR), and Ice Punch' (IP). Plants were pretreated with SA, $\mathrm{CaCl}_{2}$, or combined $\mathrm{SA}$ and $\mathrm{CaCl}_{2}$ and then exposed to a temperature of $42{ }^{\circ} \mathrm{C}$ for 1 hour. Changes in the relative injury (RI) percentage, malondialdehyde (MDA) content, and antioxidant enzyme activities were determined. All plants were then placed in an environment-controlled greenhouse for 14 days and evaluated. Lateral bud sprouting (\%), new leaf numbers, and phenotypic appearance were recorded. Results revealed that the three poinsettia cultivars varied in their appearance, morphological growth patterns, and ability to tolerate high-temperature stress. Plant growth of 'Noel' was more robust than that of 'WR' and 'IP', which were considerably affected by heat stress, resulting in brown, withered leaves and defoliation. In general, the effects of the combined application of $\mathrm{SA}$ and $\mathrm{CaCl}_{2}$ on heat-tolerant 'Noel' were superior to those of individual applications and no treatment (for control groups) in terms of the RI percentage, lateral bud sprouting (\%), and appearance under heat stress. Application of combined $\mathrm{SA}$ and $\mathrm{CaCl}_{2}$ for 'Noel' plants was more beneficial for enhancing catalase activity and resulted in the effective alleviation of decreased malondialdehyde content under heat stress. Treatment including $200 \mu \mathrm{M} \mathrm{SA}$ and $10 \mathrm{mM} \mathrm{CaCl}_{2}$ may alleviate heat stress and may prove useful in breeding programs focused on improving poinsettia cultivars.
\end{abstract}

Heat stress affects the phenotype of plants, causing leaf etiolation and wilting, and alters the anatomy, physiology, and photosynthetic capability of plants (Szymańska et al., 2017). High-temperature conditions can potentially cause the accumulation of reactive oxygen species (ROS), including $\mathrm{H}_{2} \mathrm{O}_{2}$, that function as signal transduction molecules and can cause extensive cellular damage. To prevent damage, ROS are removed by antioxidant machinery; however, removal can be impaired by the effects of stresses themselves (Baxter et al., 2014). The unfavorable effects of heat can be alleviated by thermo-tolerance induced by exogenous application of plant growth regulators and osmoprotectants, or by the gradual application of temperature stress. Both salicylic acid (SA) and calcium chloride $\left(\mathrm{CaCl}_{2}\right)$ are signal molecules known for their roles in plant adaptation to changing environments. They influence various stress responses and regulate the physiological and biochemical mechanisms in plants that have adapted to adverse environmental conditions (Janda and Ruellan, 2015; Laanemets et al., 2013).

$\mathrm{SA}$, a small phenolic compound, is known as a stress defense activator and has a significant role in regulating physiological processes in plants involved in the response to heat stress (Boatwright and Karolina, 2013). The application of SA enhances the photosynthetic rate and maintains the stability of cell membranes by regulating enzymatic activities (Ghanta et al., 2014). In addition, SA treatments induce the synthesis of antioxidants and cardenolides, which may have significant roles in resistance to hightemperature stress (Cingoz and Gurel, 2016). In response to heat stress, an inward calcium flux, which is most likely activated by a temperature-induced increase in the fluidity of plasma membranes, is considered to be the primary pathway for heat signal transduction (Mittler et al., 2012). Calcium is known to protect the integrity of cell membranes, reduce membrane permeability, and prevent ion leakage caused by environmental stresses. Specialized transport proteins, namely cation channels, are in charge of $\mathrm{Ca}^{2+}$ influxes, which not only supply $\mathrm{Ca}^{2+}$ for metabolic and structural needs but also function in the signaling mechanisms of many cascades (Kitagawa and Yoshizaki, 1998). Exogenous application of $\mathrm{CaCl}_{2}$ has become an important research topic due to concerns about the effects of climate change on plants. Several studies showed that $\mathrm{CaCl}_{2}$ is of pivotal importance for various regulatory mechanisms in plants as a secondary messenger by controlling a variety of cellular processes such as antioxidant enzyme activity and lipid peroxidation under heat stresses, which might alleviate heat injury and initiate cellular repair (Khan et al., 2010; Tan et al., 2011).

Heat intolerance is a major constraint in poinsettia cultivation. Heat stresses inhibit poinsettia growth, lead to poor branching and flowering delay, and even produce crippled, distorted, and puckered leaves (Ecke et al., 2004). However, the effects of high temperatures on poinsettia morphology have not been adequately studied. Heat tolerance can be improved by genetic selection as well as by the use of exogenous regulators, which aid in the adaptation of physiological responses of plants. For example, the combined application of $\mathrm{SA}$ and $\mathrm{CaCl}_{2}$ improved the growth and mineral nutrition of tomatoes during salt stress (Manaa et al., 2014). Studies of SA and $\mathrm{CaCl}_{2}$, individually or combined, for wheat under salt stress revealed that their combined application more effectively reduced oxidative stress (Al-Whaibi et al., 2012). Furthermore, the use of SA and $\mathrm{CaCl}_{2}$ protected Rhododendron from injuries induced by heat stress (Shen et al., 2016). However, a limited number of studies have investigated the heat resistance of poinsettia, and the influence of 
$\mathrm{SA}$ and $\mathrm{CaCl}_{2}$ pretreatment on heat tolerance in poinsettia has never been reported. Because of its poor thermal resistance and growth difficulties, commercial poinsettias are currently cultivated in greenhouses, which requires a great deal of energy, resources, and workforce. The ways in which specific cultivars behave in response to adverse conditions must be determined to aid in breeding programs focused on this problem. Therefore, the influences of SA and $\mathrm{CaCl}_{2}$ treatments, applied alone and in combination, on poinsettia were assessed by observing changes in the physiology and morphology of plants exposed to high temperatures. The aim of this study was to determine how SA and $\mathrm{CaCl}_{2}$ affect both the physiology and morphology of three modern cultivars of poinsettia subjected to high temperatures. The induced heat stress tolerance response may be directly linked to the coordinated response of enzymatic antioxidants, and $\mathrm{CaCl}_{2}$ and SA could effectively alleviate the inhibitory effects of heat stress. Knowledge of heat-responsive enzymes is critical for enabling the further understanding of molecular mechanisms of stress tolerance. The results can be used to improve the thermo-tolerance of poinsettia, and they can be used to develop management practices for its cultivation in gardens, reduce energy consumption, and enhance cultivation during the summer.

\section{Materials and Methods}

The project consisted of two experiments. The first directly compared cultivars and chemical treatments using various physiological and morphological parameters. The second evaluated the efficacy of an optimization treatment for a heat-tolerant cultivar in response to physiological measurements under high temperatures.

\section{Expt. 1: Effects of six treatments on four measurements of three poinsettia cultivars under high temperatures}

Plant materials and culture conditions. Plants of the poinsettia (Euphorbia pulcherrima Willd.) cultivars Noel, Winter Rose (WR), and Ice Punch (IP) were obtained from a local shop in Taoyuan City, Taiwan, in June 2017. 'Noel' is the main cultivar in Taiwan because of its high-quality and variable plant formats. This plant has great upright branching, leaves that are dark red and silk-like, and large, attractive bracts with a beautiful round habit. 'WR' is an upright poinsettia with ruffled red bracts at the top, and the colored bracts curl under like a large rose-like bloom. 'IP' has variegated garnet and creamy, bright red bracts with a blaze of white down the middle of each bract. The leaves are dark green and heavily pointed. All plants were received as 3-week rooted cuttings that were $9 \mathrm{~cm}$ tall; they were transplanted into $9-\mathrm{cm}$ plastic pots $(200 \mathrm{~mL})$ containing commercial potting soil with a $4: 1(\mathrm{v} / \mathrm{v})$ mixture of peat moss and perlite, and then placed in an environment-controlled greenhouse at
National Taiwan University (NTU, latitude $25.01^{\circ} \mathrm{N}$ ), where the average temperature was $31.8^{\circ} \mathrm{C}$ and the maximum temperature was $39.7{ }^{\circ} \mathrm{C}$ with 14 -h daylengths during June and July 2017. Plants were watered twice each week, and a compound fertilizer solution $(20 \mathrm{~N}-8.8 \mathrm{P}-16.6 \mathrm{~K}$ water-soluble fertilizer at $0.5 \mathrm{~g} \cdot \mathrm{L}^{-1}$ ) was applied weekly throughout the experiment. Plants were grown for 3 weeks, and those with a uniform size with seven nodes were selected and randomly placed in a growth chamber under irradiance of $180 \mu \mathrm{mol} \cdot \mathrm{m}^{-2} \cdot \mathrm{s}^{-1}$, a $14-\mathrm{h}$ photoperiod, day/night temperatures of $34 / 28^{\circ} \mathrm{C}$, and relative humidity of $80 \%$ for 1 week. The plants were watered frequently to keep the growth substrate moist during the experiment. Then, the leaves were sprayed until saturated with solutions of different concentrations of SA (200 and $400 \mu \mathrm{M})$ and $\mathrm{CaCl}_{2}$ $(10 \mathrm{~mm})$ alone or in combination for $5 \mathrm{~h}$. The concentrations and durations of the chemical solutions were selected based on data from our preliminary study (data not shown) and the work of Jacques et al. (1991). Plants sprayed with water only were used as controls. When combined treatments were used, $\mathrm{SA}$ and $\mathrm{CaCl}_{2}$ were fully mixed. Plants were sprayed until all leaves had been covered and then left to dry. After $5 \mathrm{~h}$, all plants were exposed to a temperature of $42{ }^{\circ} \mathrm{C}$ for $1 \mathrm{~h}$, which was sufficient to detect differences among cultivars with known differences in summer landscape performances (unpublished data). After $1 \mathrm{~h}$ of heat stress, leaf samples were collected to be used in relative injury (RI) and morphological analyses.

Relative injury. The percentage of RI (RI\%) was measured as the conductivity of electrolyte leakage (EL) from the uppermost fully expanded leaf of each plant over a range of temperatures. Leaf discs $1 \mathrm{~cm}$ in diameter were treated by heating to $55^{\circ} \mathrm{C}$ for $15 \mathrm{~min}$. Heat-treatment tubes were then cooled to $25{ }^{\circ} \mathrm{C}$, and both the control and treatment tubes were filled with $15 \mathrm{~mL}$ of distilled water and incubated at $6^{\circ} \mathrm{C}$ for $24 \mathrm{~h}$ to allow diffusion of electrolytes from the leaf discs. An initial conductance measurement (R1) was performed using a conductivity meter (Model SC-170; SunTex, Taipei, Taiwan). Both the control and heat-treatment tubes were then autoclaved at $121{ }^{\circ} \mathrm{C}$ for $15 \mathrm{~min}$ to lyse all cells and release all of the electrolytes, and final conductance measurements (R2) were performed. RI\% induced as a result of the initial $50{ }^{\circ} \mathrm{C}$ temperature treatment was then calculated as follows: RI $(\%)=(\mathrm{R} 1 / \mathrm{R} 2) \times$ 100\% (Onwueme, 1979).
Lateral bud sprouting and new leaves of plants. After five chemical treatments, treated plants and untreated control plants were housed in heat growth chambers for $1 \mathrm{~h}$; all plants were then placed in the aforementioned greenhouse at NTU for $14 \mathrm{~d}$, and lateral bud sprouting (\%), new leaves (number), and appearance of all test plants were evaluated. Plants in all treatment groups were irrigated with the aforementioned compound fertilizer solution twice per week throughout the experiment to avoid drought stress. The total number of shoots and the number of sprouted lateral buds were recorded on the day when the labeled lateral buds were counted and divided by the total number of shoots. The number of new leaves (nonfully expanded leaves) was also scored on day 14 for each of the labeled shoots of all test plants.

Appearance. Throughout the experiment, the morphology of plants in the vegetative stage was observed and rated on a scale of 1 to 5 points based on the level of heat-induced injury (Fig. 1):

Level 1: $>6$ leaves had become brown, withered, and abscised;

Level 2: 5 or 6 leaves had become brown, withered, and abscised;

Level 3: 3 or 4 leaves had become brown, withered, and abscised;

Level 4: 1 or 2 leaves had become brown and withered; and

Level 5: normal growth.

\section{Expt. 2: Optimization of treatment of a heat-tolerant cultivar under high temperatures for $1 \mathrm{~h}$}

After investigating differences in the five chemical treatments among cultivars used in the first experiment, malondialdehyde (MDA) and antioxidant activity were used to achieve maximum separation among cultivars and treatments based on cultivars with significantly different performances. All test plants were subjected to the same experimental procedure as used during Expt. 1.

Determination of lipid peroxides. MDA is the final decomposition product of lipid peroxidation, and it is used as an index of the lipid peroxidation status. Thiobarbituric acid (TBA)-reactive substances representing lipid peroxidation products were extracted by homogenization of $100 \mathrm{mg}$ of leaves in $5 \mathrm{~mL}$ of $0.6 \%(\mathrm{v} / \mathrm{v})$ TBA solution in $10 \%(\mathrm{v} / \mathrm{v})$ trichloroacetic acid (TCA). The mixture was heated to $95{ }^{\circ} \mathrm{C}$ for $30 \mathrm{~min}$, and the reaction

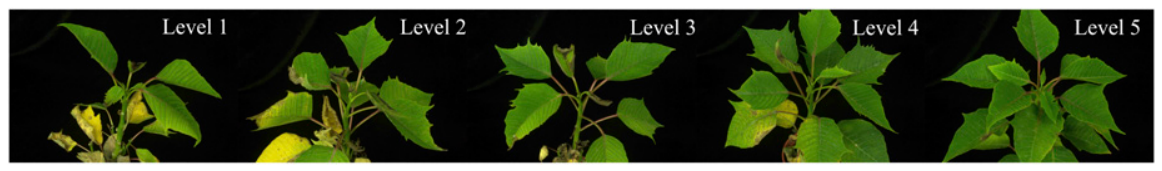

Fig. 1. Injurious levels of heat stress and effects of salicylic acid (SA) and/or $\mathrm{CaCl}_{2}$ application on the morphological appearance of poinsettia 'Noel' under heat stress. Level 1 ( 1 point): $>6$ leaves had become brown, withered, and defoliated. Level 2 ( 2 points): 5 or 6 leaves had become brown, withered, and defoliated. Level 3 (3 points): 3 or 4 leaves had become brown, withered, and defoliated. Level 4 (4 points): 1 or 2 leaves had become brown and withered. Level 5 (5 points): normal growth. 
was stopped by rapid placement in an ice bath. The cooled mixture was centrifuged at $13,000 g_{n}$ for $10 \mathrm{~min}$ at $25{ }^{\circ} \mathrm{C}$, and the absorbance values of the supernatant at 532 and $600 \mathrm{~nm}$ were determined using a spectrophotometer (U2800A; Hitachi, Tokyo, Japan). After subtracting the nonspecific turbidity at $600 \mathrm{~nm}$, the MDA concentration (nmol. $\mathrm{g}^{-1}$ ) was determined by its molar extinction coefficient of $155 \mathrm{~mm}^{-1} \cdot \mathrm{cm}^{-1}$ (Kosugi and Kikugawa 1985).

Antioxidant enzyme quantification. All enzymes were extracted by grinding $0.2 \mathrm{~g}$ of frozen visually healthy leaf tissues in liquid $\mathrm{N}_{2}$, acid-washed sand, $50 \mathrm{~mm} \mathrm{Mes} /$ KOH buffer (pH 6.8), $40 \mathrm{~mm} \mathrm{KCl,} 2 \mathrm{~mm}$ $\mathrm{CaCl}_{2}$, and $1 \mathrm{~mm}$ ascorbate. After centrifugation $\left(13,000 g_{\mathrm{n}}\right.$ for $20 \mathrm{~min}$ at $\left.4{ }^{\circ} \mathrm{C}\right)$, the supernatants were immediately used for enzyme activity assays. Bradford's method (Bradford, 1976) was used to determine the soluble protein content of the samples. All enzyme activity assays were conducted at $20{ }^{\circ} \mathrm{C}$ in a reaction volume of $0.5 \mathrm{~mL}$. Catalase (CAT) (EC 1.11.1.6) was measured spectrophotometrically using the method of Hwang and VanToai (1991) in a reaction mixture containing $50 \mathrm{~mm} \mathrm{KH}_{2} \mathrm{PO}_{4}$ buffer ( $\mathrm{pH} 7.0$ ) and $15 \mathrm{mM} \mathrm{H}_{2} \mathrm{O}_{2}$, with $100 \mu \mathrm{L}$ of extract for reaction initiation. Activity was expressed as the change in absorbance at $240 \mathrm{~nm}$ after degradation with $50 \mathrm{~mm} \mathrm{H}_{2} \mathrm{O}_{2}$. CAT activity was calculated using an extinction coefficient of $39.4 \mathrm{~mm}^{-1} \cdot \mathrm{cm}^{-1}$ for $\mathrm{H}_{2} \mathrm{O}_{2}$.

Superoxide dismutase (SOD) (EC 1.15.1.1) activity was determined using a SOD assay kit with WST (Dojindo Molecular Technology, Gaithersburg, MD). The SOD assay kit used a WST working solution of 2-(4-iodophenyl)-3-(4nitrophenyl)-5-(2,4-disulfophenyl)-tetrazolium, which produced a water-soluble formazan dye on reduction with superoxide anions $\left(\cdot \mathrm{O}^{2-}\right)$. The rate of reduction of $\mathrm{O}^{2-}$ was linearly related to xanthine oxidase activity and inhibited by SOD. Therefore, $50 \%$ of the SOD inhibitory activity could be measured at an absorbance of $450 \mathrm{~nm}$. The specific activity of SOD (i.e., the inhibition rate) was calculated using the equation described in the protocol included with the kit. One unit of enzyme was defined as the amount of enzyme required to decompose $1 \mu \mathrm{mol}$ of substrate per minute [ $g$ fresh weight $(\mathrm{FW})]^{-1}$.

Statistical analysis. Data were determined in triplicate, and the results are expressed as the mean \pm SD. An analysis of variance (ANOVA) involving the least significant difference (LSD) test and Student's $t$ test at $P \leq 0.05$ was performed using SAS version 9 (SAS Institute, Cary, NC). The experiment was performed twice independently with a randomized design for the growth environment, sampling day, and physiological analyses.

\section{Results}

Effects of chemical treatments on the RI, lateral bud sprouting, new leaves, and appearance of cultivars under heat stress. RI values showed significant differences among varieties. The RI\% at $42{ }^{\circ} \mathrm{C}$ of 'Noel' in the control group $(16.68 \% \pm 1.25 \%)$ was significantly lower than that of ' $W R$ ' $(31.81 \% \pm 5.30 \%)$ and 'IP' $(34.14 \% \pm$ $6.20 \%$ ), indicating that 'Noel' was more heat-tolerant than 'WR' and 'IP' (Table 1). 'Noel' RI\% was also significantly lower (range, $12.84 \% \pm 1.24 \%$ to $15.94 \% \pm$ $1.78 \%$ ) than that of 'WR' (range, 19.05\% \pm $1.86 \%$ to $23.71 \% \pm 1.53 \%$ ) and 'IP' (range, $20.14 \% \pm 1.64 \%$ to $24.79 \% \pm 5.31 \%$ ) for all chemical treatments, making it easy to detect differences between cultivars in response to heat stress. In addition, RI\% values of all chemical treatments within each cultivar were significantly lower than that of the control, except for treatment with $400 \mu \mathrm{M}$ SA for 'Noel'.

Comparing sprouting rates of lateral buds of all test plants indicated that 'WR' was the most tolerant relative to the control $(30.75 \pm$ 3.71 ) as a result of all chemical treatments (range, $52.02 \pm 11.95$ to $95.07 \pm 18.05$ ) Compared with a single chemical treatment and the control group, all combined chemical treatments induced higher sprouting rates of lateral buds in all cultivars, except for treatment with $400 \mu \mathrm{M}$ SA plus $10 \mathrm{mM} \mathrm{CaCl}_{2}$ for 'WR' (Table 1).

Both 'WR' and 'IP' had more new leaves after all chemical treatments compared to the control group. The control group and 'Noel' after any treatment showed no significant differences in new leaf numbers. Furthermore, all chemical treatments produced significantly more new leaves for ' $W R$ ' (26.33 \pm 3.62 to $44.33 \pm 2.02)$ than for 'IP' $(19.33 \pm$ 1.15 to $24.33 \pm 1.29$ ).

After $1 \mathrm{~h}$ of exposure to $42^{\circ} \mathrm{C}$ and $14 \mathrm{~d}$ of heat stress, plants sprayed with SA and $\mathrm{CaCl}_{2}$, alone or combined, showed some changes in plant growth. The leaves had turned brown and withered, and the plants had defoliated with different levels of injury and damage rates (Supplemental Figs. 1-3), depending on the treatment. Therefore, plants treated with exogenous SA and $\mathrm{CaCl}_{2}$, alone or in combination, were markedly protected from heat-induced growth inhibition. In contrast, the control group of all species had the highest degree of injury (Table 1). The morphological quality of plants in each pot was visually rated using a scale of 1 to 5 , with 5 indicating the best of all quality components and 1 indicating mostly brown, withered, and defoliated leaves. The 'Noel' control group exhibited significantly better appearance $(3.2 \pm 0.20)$ than did 'WR' $(1.4 \pm$ $0.24)$ and 'IP' $(1.6 \pm 0.40)$ with hightemperature treatments. For all treatments,

Table 1. Effects of salicylic acid (SA) and calcium chloride $\left(\mathrm{CaCl}_{2}\right)$ treatments on the relative injury percentage (RI\%), lateral buds sprouting (\%), new leaves (no.), and appearance among poinsettia cultivars Noel, Winter Rose, and Ice Punch under $42{ }^{\circ} \mathrm{C}$ treatment for $1 \mathrm{~h}$.

\begin{tabular}{|c|c|c|c|c|c|}
\hline Cultivar & Treatment & RI (\%) & Lateral buds sprouting (\%) & New leaves (no.) & Appearance $^{\mathrm{x}}$ \\
\hline \multirow[t]{4}{*}{ Noel } & Control & $16.68 \pm 1.25 \mathrm{a}^{\mathrm{x}} \mathrm{B}^{\mathrm{y}}$ & $37.47 \pm 6.65 \mathrm{bB}$ & $26.67 \pm 2.57 \mathrm{aA}$ & $3.2 \pm 0.20 \mathrm{bA}$ \\
\hline & SA $400 \mu \mathrm{M}$ & $15.94 \pm 1.78 \mathrm{abB}$ & $44.13 \pm 13.01 \mathrm{abA}$ & $30.33 \pm 1.29 \mathrm{aA}$ & $4.2 \pm 0.20 \mathrm{aA}$ \\
\hline & $\mathrm{CaCl}_{2} 10 \mathrm{~mm}$ & $13.68 \pm 2.06 \mathrm{cB}$ & $44.56 \pm 13.50 \mathrm{abB}$ & $26.33 \pm 2.76 \mathrm{aB}$ & $4.2 \pm 0.24 \mathrm{aA}$ \\
\hline & $\mathrm{SA} 400 \mu \mathrm{M}+\mathrm{CaCl}_{2} 10 \mathrm{~mm}$ & $12.84 \pm 1.24 \mathrm{cB}$ & $51.99 \pm 14.36 \mathrm{aA}$ & $32.33 \pm 3.93 \mathrm{aA}$ & $4.6 \pm 0.24 \mathrm{aA}$ \\
\hline \multirow[t]{4}{*}{ Winter Rose } & Control & $31.81 \pm 5.30 \mathrm{aA}$ & $30.75 \pm 3.71 \mathrm{cB}$ & $14.67 \pm 2.47 \mathrm{cB}$ & $1.4 \pm 0.24 \mathrm{cB}$ \\
\hline & SA $200 \mu \mathrm{M}$ & $21.45 \pm 2.45 \mathrm{bcA}$ & $63.33 \pm 8.89 \mathrm{bA}$ & $26.33 \pm 3.62 \mathrm{bA}$ & $2.8 \pm 0.58 \mathrm{bB}$ \\
\hline & SA $200 \mu \mathrm{M}+\mathrm{CaCl}_{2} 10 \mathrm{mM}$ & $21.39 \pm 2.74 \mathrm{bcA}$ & $95.07 \pm 17.90 \mathrm{aA}$ & $42.00 \pm 7.86 \mathrm{aA}$ & $4.2 \pm 0.24 \mathrm{aA}$ \\
\hline & SA $400 \mu \mathrm{M}+\mathrm{CaCl}_{2} 10 \mathrm{mM}$ & $23.71 \pm 1.53 \mathrm{bA}$ & $56.35 \pm 8.13 \mathrm{bA}$ & $37.00 \pm 11.69 \mathrm{abA}$ & $4.4 \pm 0.24 \mathrm{aA}$ \\
\hline \multirow[t]{5}{*}{ Ice Punch } & Control & $34.14 \pm 6.20 \mathrm{aA}$ & $42.74 \pm 13.30 \mathrm{bA}$ & $17.67 \pm 2.08 \mathrm{bB}$ & $1.6 \pm 0.40 \mathrm{cB}$ \\
\hline & SA $200 \mu \mathrm{M}$ & $24.79 \pm 5.31 \mathrm{bA}$ & $43.91 \pm 15.70 \mathrm{abB}$ & $19.33 \pm 1.15 \mathrm{bB}$ & $2.8 \pm 0.49 \mathrm{bB}$ \\
\hline & SA $400 \mu \mathrm{M}$ & $24.38 \pm 4.64 \mathrm{bA}$ & $44.12 \pm 8.28 \mathrm{abA}$ & $23.33 \pm 1.89 \mathrm{aB}$ & $3.4 \pm 0.24 \mathrm{abB}$ \\
\hline & $\mathrm{CaCl}_{2} 10 \mathrm{~mm}$ & $21.33 \pm 2.09 \mathrm{bA}$ & $44.56 \pm 14.46 \mathrm{abB}$ & $24.33 \pm 4.58 \mathrm{aB}$ & $3.6 \pm 0.24 \mathrm{abB}$ \\
\hline & SA $200 \mu \mathrm{M}+\mathrm{CaCl}_{2} 10 \mathrm{mM}$ & $22.37 \pm 4.27 \mathrm{bA}$ & $55.86 \pm 8.36 \mathrm{aB}$ & $23.67 \pm 4.81 \mathrm{aB}$ & $4.8 \pm 0.20 \mathrm{aA}$ \\
\hline
\end{tabular}

${ }^{\mathrm{z}}$ Among six treatments (Control, SA $200 \mu \mathrm{M}$, SA $400 \mu \mathrm{M}, \mathrm{CaCl}_{2} 10 \mathrm{mM}$, SA $200 \mu \mathrm{M}+\mathrm{CaCl}_{2} 10 \mathrm{mM}$, and SA $400 \mu \mathrm{M}+\mathrm{CaCl}_{2} 10 \mathrm{mM}$ ) for each parametric measurement of the same variety within a column, means with the same lowercase letter do not significantly differ according to the least significant difference test at $P \leq 0.05$.

${ }^{y}$ Among three parametric measurements (Noel, Winter Rose, and Ice Punch) for the same treatment in different varieties across columns, means with the same capital letter do not significantly differ according to the least significant difference test at $P \leq 0.05$.

${ }^{\mathrm{x}}$ Appearance was rated as 1 to 5 points based on the level of heat-induced injury. 
results revealed that the appearance of the plants treated with a combination of SA and $\mathrm{CaCl}_{2}$ was better than that of plants treated with $\mathrm{SA}$ alone or $\mathrm{CaCl}_{2}$ alone. $M D A$ contents and the enzymatic activities of 'Noel' under heat stress. Results from Expt. 1 showed that heat-tolerant 'Noel' performed better than heat-sensitive 'WR' and 'IP' in terms of RI\% measurements and appearance. Because of its efficacy, a combined chemical treatment including $200 \mu \mathrm{M}$ SA and $\mathrm{CaCl}_{2} 10 \mathrm{~mm}$ was considered an optimized and economic treatment of 'Noel' based on physiological measurements at $42{ }^{\circ} \mathrm{C}$ for $1 \mathrm{~h}$. As shown in Table 2, the combined exogenous application of SA and $\mathrm{CaCl}_{2}$ significantly decreased the MDA content $\left(69.35 \pm 4.16 \mathrm{nmol} \cdot \mathrm{g}^{-1}\right)$ compared with that of untreated control plants $(101.51 \pm 8.21$ nmol. $\mathrm{g}^{-1}$ ) under heat stress.

SOD and CAT activities in leaves were examined to investigate whether changes in MDA and $\mathrm{H}_{2} \mathrm{O}_{2}$ contents were associated with higher antioxidant activity levels. As shown in Table 2, various enzymes acted differently under heat stress; however, each enzyme was not necessarily equally significant in regard to protecting 'Noel' plants against heat stress. CAT activity $(0.14 \pm 0.02$ $\mathrm{U} / \mathrm{g}$ ) was significantly increased after the combined chemical treatment compared with that of control plants $(0.02 \pm 0.01 \mathrm{U} / \mathrm{g})$ exposed to $1 \mathrm{~h}$ of stress. However, SOD activity resulting from the simultaneous application of $\mathrm{SA}$ and $\mathrm{CaCl}_{2}$ was not significantly different compared with that of the control group under heat stress.

\section{Discussion}

Because of the interest in potted plants, their demand has increased (Renu and Srivastava, 2013). One popular ornamental potted plant is poinsettia. Taiwan has both tropical and subtropical regions where daily temperatures exceed $32{ }^{\circ} \mathrm{C}$ during the summer (June to September), thereby reducing the quality and quantity of poinsettia. Currently, no method apart from field observations has been developed for phenotyping high-temperature susceptibility of garden poinsettia plants. There are several physiological stress markers that can be measured in plants that provide insight regarding how cell membranes behave under heat stress conditions, and the RI\% is one of the most commonly used parameters. Quantifying high-temperature stress and rapidly screening poinsettia cultivars for high-temperature susceptibility are dependent on the temperature
Effects of the combined treatment on

and duration of treatment. By optimizing the stress duration, we maximized differences in the RI\% among three cultivars. During Expt. 1 , the decision to subject plants to stress for $1 \mathrm{~h}$ at $42{ }^{\circ} \mathrm{C}$ was based on our previous observations after subjecting plants to stress for $30 \mathrm{~min}$ at $45^{\circ} \mathrm{C}$, which did not maximize the differences in the RI\% among cultivars. In general, all differences detected between cultivars corresponded to the appearance, with 'Noel' having superior appearance compared to 'WR' and 'IP' under high temperatures. None of the 'Noel' plants showed any visible signs of stress immediately after heat chamber treatment with any of the chemical applications. Evaluations at $14 \mathrm{~d}$ after heat stress also revealed no visible signs of hightemperature damage, such as shoot burn or leaf necrosis (Supplemental Fig. 1). This experiment was conducted to test the efficacy of these chemical applications for improving plant growth by enhancing the tolerance of plants against high-temperature stress. Our main focus was to reduce the impact of heat stress during vegetative growth stages of plants and to develop a strategy to improve the heat tolerance of poinsettia. Expt. 2 combined optimized treatments from Expt. 1 to evaluate differences in high-temperature tolerance among cultivars. In terms of the RI $\%$, 'Noel' exhibited more vigor than 'WR' and 'IP' with combined chemical treatments. Because of economic considerations, $200 \mu \mathrm{M}$ SA plus $\mathrm{CaCl}_{2} 10 \mathrm{~mm}$ was used for Expt. 2 .

Among the various abiotic elicitors, $\mathrm{SA}$ is an effective stress-signaling molecule and elicitor, and its ability to increase the accumulation of secondary metabolites in cultured plant cells and tissues has been extensively studied (Sivanandhan et al., 2012). SA causes increased SOD and CAT activities in response to heat stress application (Chakraborty and Tongden, 2005). Chen and Kuc (1999) showed that $\mathrm{Ca}^{2+}$ was able to regulate both intracellular and extracellular transportation of SA. Several studies established that $\mathrm{Ca}^{2+}$ cooperates with SA by enhancing various types of resistance in plants. Chen et al. (2001) reported that $\mathrm{Ca}^{2+}$ controlled the movement of SA in and out of plant cells. Guo et al. (2015) demonstrated that SA treatment first led to $\mathrm{Ca}^{2+}$ release from internal stores of Salvia miltiorrhiza, and that a large amount of $\mathrm{Ca}^{2+}$ effluxed from apoplasts in cell culture. Lan et al. (2016) illustrated that aluminum and SA increased cytosolic $\mathrm{Ca}^{2+}$ concentrations in soybean roots, and that SA could mediate cellular $\mathrm{Ca}^{2+}$ levels in soybean. Interestingly, the simultaneous addition of $\mathrm{SA}$ and $\mathrm{Ca}^{2+}$ reduced $\mathrm{NaCl}$ induced oxidative stress in wheat more

Table 2. Effects of salicylic acid (SA) and calcium chloride $\left(\mathrm{CaCl}_{2}\right)$ treatments on the malondialdehyde (MDA) content and activities of superoxide dismutase (SOD) and catalase (CAT) of poinsettia 'Noel' under $42{ }^{\circ} \mathrm{C}$ treatment for $1 \mathrm{~h}$.

\begin{tabular}{lccc}
\hline Treatment & MDA $(\mathrm{nmol} / \mathrm{g})$ & SOD (unit/g) & CAT (unit/g) \\
\hline Control & $101.51 \pm 8.21$ & $36.00 \pm 5.38$ & $0.02 \pm 0.01$ \\
$200 \mu \mathrm{M} \mathrm{SA}+\mathrm{CaCl}_{2} 10 \mathrm{mM}$ & $69.35 \pm 4.16$ & $32.36 \pm 5.02$ & $0.14 \pm 0.02$ \\
$t$ test & $* *$ & $\mathrm{NS}$ & $*$ \\
\hline Ns, ${ }^{*}, * *$ Nonsignificant or significant difference at $P \leq 0.05$ or 0.01, respectively, according to Student's \\
$t$ test.
\end{tabular}

effectively by preventing MDA accumulation (Al-Whaibi et al., 2012). Determination of MDA is a sensitive and rapid method used to evaluate heat tolerance in plants ( $\mathrm{Wu}$ and Waller, 1983). Under heat stress, $\mathrm{Ca}^{2+}$ can maintain antioxidant activity in some coolseason grasses (Jiang and Huang, 2001). A foliar spray of $\mathrm{Ca}^{2+}(10 \mathrm{~mm})$ before heat stress $\left(42{ }^{\circ} \mathrm{C}, 2 \mathrm{~h}\right)$ during the grain-filling stage proved to be beneficial for the growth of wheat (Goswami et al., 2015). Calcium application in the form of $\mathrm{CaCl}_{2}$ increased the MDA content and stimulated SOD and CAT activities, which could be the reason for the induction of heat tolerance (Kolupaev et al., 2005). In our study, thermal damage to cell membranes was characterized by a marked increase in the RI\%. The injury inflicted on leaf tissues under high temperatures weakened cell membranes, which led to leakage of electrolytes from the cell. Higher conductivity values indicated more extensive cell membrane injury.

ROS are clearly necessary for plant growth and act as essential secondary messengers for cell metabolism (Choudhury et al., 2017). Along with ROS, changes in cytosolic $\mathrm{Ca}^{2+}$ have been linked to rapid systemic signaling activity throughout plants (Gilroy et al., 2016). Calcium acts at a convergence point for integrating different signals, and it is a ubiquitous cellular regulator involved in a wide range of physiological processes and responses to heat stress (Steinhorst and Kudla, 2014). Heat stress induces the overproduction of ROS in plant tissues, thereby seriously affecting the balance between the generation and degradation of ROS. Furthermore, plants respond quickly to various heat stresses by regulating complex physiological, biochemical, and molecular mechanisms for acclimation and adaptation to the stress. It is also possible that both calcium and ROS could be important modulators of cellular signaling of transduction events following heat stress injury. The development of short-term heat stress in leaves was more gradual or perhaps delayed by $\mathrm{CaCl}_{2}$ treatment. High concentrations of ROS can cause detrimental effects due to their ability to cause lipid peroxidation of cellular membranes, protein denaturalization, and impaired enzymatic activities (Bose et al., 2014). Therefore, a delicate balance between ROS production and their detoxification may exist in all oxygendependent organisms. Antioxidant enzymes act as ROS scavengers to mitigate oxidative injury and maintain metabolic functions. Photo-respiratory ROS production is primarily mitigated by CAT, and Arabidopsis mutants deficient in peroxisomal CAT have been a major tool for studying $\mathrm{H}_{2} \mathrm{O}_{2}$ signaling during stressful conditions (Kerchev et al., 2016). In this study, we revealed that $\mathrm{Ca}^{2+}$ and SA increased CAT activities in leaves exposed to $42^{\circ} \mathrm{C}$. These results indicated that $\mathrm{Ca}^{2+}$ and SA may alleviate heat-induced oxidative stress in the poinsettia by upregulating CAT activity to prevent the accumulation of $\mathrm{H}_{2} \mathrm{O}_{2}$ and $\mathrm{O}_{2}^{-}$. Induction of CAT 
activity in response to thermal stress triggered acclimation to heat stress. $\mathrm{Ca}^{2+}$ can alleviate $\mathrm{H}_{2} \mathrm{O}_{2}$ and $\mathrm{O}_{2}{ }^{-}$toxicity in poinsettia leaves when $\mathrm{Ca}^{2+}$ channels are open; however, under heat stress, the effects of SA on $\mathrm{Ca}^{2+}$ levels were regulated by $\mathrm{Ca}^{2+}$ through the $\mathrm{Ca}^{2+}$ channel. $\mathrm{Ca}^{2+}$ channel-blocker drugs and $\mathrm{Ca}^{2+}$ chelators aggravated the effects of heat stress, suggesting that the cellular influx of $\mathrm{Ca}^{2+}$ ions is essential for triggering responses to heat stress (Yang et al., 2013). $\mathrm{Ca}^{2+}$ ions protect cell membranes from heat injury, possibly by directly binding to cell membranes to reduce their fluidity under high temperatures. SA is involved in $\mathrm{Ca}^{2+}$ mediated signal transduction pathways for heat tolerance. By maintaining ROS homeostasis, $\mathrm{Ca}^{2+}$ and SA help maintain better physiological process performance and optimal growth rates under heat stress.

Heat stress not only affects the phenotype of the plant but also results in a wide range of physiological and biochemical functions in plants. It has a key role in providing better adaptation to high-temperature stress. In the floriculture industry, the need for heattolerant plant cultivars is increasing because of increasing global temperatures. CAT activity was increased in 'Noel' plants by pretreatment with a combination of $\mathrm{SA}$ and $\mathrm{CaCl}_{2}$. The differential responses of antioxidant enzymes may be one of the possible mechanisms resulting in differences in temperature sensitivities of the three plant cultivars. Furthermore, CAT was directly related to the high-temperature tolerance of 'Noel'. Interactions of CAT and SOD and their involvement in scavenging ROS are complex. Different enzymes acted differently under heat stress and to $\mathrm{SA}$ and $\mathrm{CaCl}_{2}$ treatments; however, each enzyme is not necessarily equally significant in regard to protecting against heat stress. Impacts of changing enzyme activities on the heat tolerance and health of plants were affected by SA and $\mathrm{CaCl}_{2}$ applications. The balance between SOD and CAT activities in cells is crucial for determining the steady-state level of $\mathrm{O}^{2-}$ and $\mathrm{H}_{2} \mathrm{O}_{2}$ and counteracting deleterious effects of ROS. The different affinities of SOD and CAT for $\mathrm{O}^{2-}$ and $\mathrm{H}_{2} \mathrm{O}_{2}$ suggest that these two enzymes are in two different classes of $\mathrm{H}_{2} \mathrm{O}_{2}$ scavenging enzymes during environmental stress (Mittler, 2002). Higher activities of CAT and SOD in plants treated with high temperatures can reduce the accumulation of $\mathrm{H}_{2} \mathrm{O}_{2}$ and alleviate damage to cell membranes. ROS homeostasis can be maintained in plant cells by various antioxidant enzymes, and CAT activity appeared to exist in lesser amounts compared with SOD, but it was more sensitive to heat stress in plants. Presumably, components of the antioxidant system and ROS formation are favored in heat-tolerant plants. Different plant genotypes may respond to oxidative stress by upregulating antioxidant activities during high-temperature conditions, and CAT is deeply involved in this process. Therefore, CAT could be used as a physiological marker to select heat-tolerant germplasms or to create tolerant poinsettia through genetic manipulation. Combining the RI\% and MDA and CAT activities after high-temperature shock $\left(42^{\circ} \mathrm{C}\right.$ for $\left.1 \mathrm{~h}\right)$ in a heat growth chamber could be used in breeding programs to select against the most susceptible plants, resulting in more efficient use of land for evaluating new material in the field. In other words, these identified systems could be used for rapid monitoring and early detection of heat injury during the seedling stage. This means that hundreds of individual plants could be screened per day, thereby providing a scope for the discovery of individuals that exhibit tolerance to heat stress. Treatment with $200 \mu \mathrm{M} \mathrm{SA}$ and $10 \mathrm{mM} \mathrm{CaCl}_{2}$ can ameliorate heat stress and can be used as a substitute technology for developing climate-smart poinsettia plants, resulting in increased farm income. Further studies are needed to confirm the specific signal regulation and transduction components that are present in SA-mediated and $\mathrm{Ca}^{2+}$-mediated improvements of heat tolerance in 'Noel' plants through genetic modification or mutagenesis.

In conclusion, the studied cultivars differed in their sensitivity to heat stress, and the lower RI\% and better appearance led to greater heat tolerance in Noel compared with the other cultivars. $\mathrm{Ca}^{2+}$ and $\mathrm{SA}$ acted as primary signaling molecules and responded to heat stress in poinsettia, and they coordinately regulated lateral bud sprouting, new leaf numbers, and oxidative stress. Subjecting plants to $42{ }^{\circ} \mathrm{C}$ for $1 \mathrm{~h}$ resulted in $\mathrm{RI} \%$ and morphological appearance that were useful for separating cultivars in accordance with combined chemical treatments. Therefore, the RI\% can be used for screening poinsettia plants for growth in the tropics. Lateral bud sprouting and new leaves of poinsettia increased by the facilitation of a $\mathrm{Ca}^{2+}$-mediated pathway for the accumulation of SA in response to short-term heat stress. SA and $\mathrm{CaCl}_{2}$ application enhanced CAT activity and reduced the MDA level. $\mathrm{Ca}^{2+}$ and SA pretreatment seemed to provide better adaptation to heat stress, and the induced heat stress tolerance may be directly linked to the coordinated response of antioxidant molecules and the direct implication in the regulation of oxidative metabolism, which could help create better future agricultural methods in relation to current global warming predictions.

\section{Literature Cited}

Al-Whaibi, M.H., M.H. Siddiqui, and M.O. Basalah. 2012. Salicylic acid and calcium-induced protection of wheat against salinity. Protoplasma 249:769-778.

Baxter, A., R. Mittler, and N. Suzuki. 2014. ROS as key players in plant stress signalling. J. Expt. Bot. 65:1229-1240.

Boatwright, J.L. and P.M. Karolina. 2013. Salicylic acid: An old hormone up to new tricks. Mol. Plant Pathol. 14:623-634.

Bose, J., A. Rodrigo-Moreno, and S. Shabala. 2014. ROS homeostasis in halophytes in the context of salinity stress tolerance. J. Expt. Bot. 65:1241-1257.

Bradford, M.M. 1976. A rapid and sensitive method for the quantitation of microgram quantities of protein utilizing the principle of protein-dye binding. Anal. Biochem. 72:248254.

Chakraborty, U. and C. Tongden. 2005. Evaluation of heat acclimation and salicylic acid treatment as potent inducers of thermotolerance in Cicer arietinum L. Curr. Sci. 89:384-389.

Chen, H.J. and J. Kuc. 1999. $\mathrm{Ca}^{2+}$-dependent excretion of salicylic acid in tobacco cell suspension culture. Bot. Bull. Acad. Sin. 40:267-273.

Chen, H.J., W.C. Hou, J. Kuc, and Y.H. Lin. 2001. $\mathrm{Ca}^{2+-}$ dependent and $\mathrm{Ca}^{2+}$ independent excretion modes of salicylic acid in tobacco cell suspension culture. J. Expt. Bot. 52:1219-1226.

Choudhury, F.K., R.M. Rivero, E. Blumwald, and R. Mittler. 2017. Reactive oxygen species, abiotic stress and stress combination. Plant $\mathrm{J}$. 90:856-867.

Cingoz, G.S. and E. Gurel. 2016. Effects of salicylic acid on thermotolerance and cardenolide accumulation under high temperature stress in Digitalis trojana Ivanina. Plant Physiol. Biochem. 105:145-149.

Ecke, P., III, J.E. Faust, A. Higgins, and J. William. 2004. The Ecke poinsettia manual. Ball Publishing, Batavia.

Ghanta, S., R. Datta, D. Bhattacharyya, R. Sinha, D. Kumar, S. Hazra, A.B. Mazumdar, and S. Chattopadhyay. 2014. Multistep involvement of glutathione with salicylic acid and ethylene to combat environmental stress. J. Plant Physiol. 171:940-950

Gilroy, S., M. Białasek, N. Suzuki, M. Górecka, A.R. Devireddy, S. Karpiński, and R. Mittler. 2016. ROS, calcium, and electric signals: Key mediators of rapid systemic signaling in plants. Plant Physiol. 171:1606-1615.

Goswami, S., R.R. Kumar, S.K. Sharma, Y.K. Kala, K. Singh, R. Gupta, and R.D. Rai. 2015. Calcium triggers protein kinases-induced signal transduction for augmenting the thermotolerance of developing wheat (Triticum aestivum) grain under the heat stress. J. Plant Biochem. Biotechnol. 24:441-452.

Guo, H.B., N. Zhu, M.K. Deyholos, J. Liu, X.R Zhang, and J. Dong. 2015. Calcium mobilization in salicylic acid-induced Salvia miltiorrhiza cell cultures and its effect on the accumulation of rosmarinic acid. Appl. Biochem. Biotechnol. 175:2689-2702.

Hwang, S.Y. and T.T. VanToai. 1991. Abscisic acid induces anaerobiosis tolerance in corn. Plant Physiol. 97:593-597.

Jacques, D.J., R.E.J. Boerner, and J.C. Peterson. 1991. The effect of calcium spray on leaf and bract distortion, bound:Unbound calcium ratio, and calcium distribution in two poinsettia cultivars. J. Plant Nutr. 14:1391-1410.

Janda, M. and E. Ruellan. 2015. Magical mystery tour: Salicylic acid signalling. Environ. Expt. Bot. 114:117-128.

Jiang, Y. and B. Huang. 2001. Drought and heat injury to two cool-season turf grasses in relation to antioxidant metabolism and lipid peroxidation. Crop Sci. 41:436-442.

Kerchev, P.I., C. Waszczak, and A. Lewandowska. 2016. Lack of glycolate oxidase 1, but not glycolate oxidase 2, attenuates the photorespiratory phenotype of catalase2-deficient Arabidopsis. Plant Physiol. 171:1704-1719.

Khan, M.N., M.H. Siddiqui, F. Mohammad, M. Naeem, and M.M.A. Khan. 2010. Calcium chloride and gibberellic acid protect linseed (Linum usitatissimum $\mathrm{L}$.) from $\mathrm{NaCl}$ stress by inducing antioxidative defence system and osmoprotectant accumulation. Acta Physiol. Plant. 32:121-132. 
Kitagawa, Y. and K. Yoshizaki. 1998. Water stress-induced chilling tolerance in rice; putative relationship between chilling tolerance and calcium flux. Plant Sci. 137:73-85.

Kolupaev, Y.E., G.E. Akinina, and A.V. Mokrousov. 2005. Induction of heat tolerance in wheat coleoptiles by calcium ions and its relation to oxidative stress. Russ. J. Plant Physiol. 52:199 204.

Kosugi, H. and K. Kikugawa. 1985. Thiobarbituric acid reaction of aldehydes and oxidized lipids in glacial acetic acid. Lipids 20:915-920.

Laanemets, K., B. Brandt, J.L. Li, E. Merilo, Y.F. Wang, M.M. Keshwani, S.S. Taylor, H. Kollist, and J.I. Schroeder. 2013. Calcium dependent and -independent stomatal signaling network and compensatory feedback control of stomatal opening via $\mathrm{Ca}^{2+}$ sensitivity priming. Plant Physiol. 163:504-513.

Lan, T., J. You, L. Kong, M. Yu, M. Liu, and Z. Yang. 2016. The interaction of salicylic acid and $\mathrm{Ca}^{2+}$ alleviates aluminum toxicity in soybean (Glycine max L.). Plant Physiol. Biochem. 98:146-154.
Manaa, A., E. Gharbi, H. Mimouni, S. Wasti, S. Aschi-Smiti, S. Lutts, and H. Ben Ahmed. 2014. Simultaneous application of salicylic acid and calcium improves salt tolerance in two contrasting tomato (Solanum lycopersicum) cultivars. S. Afr. J. Bot. 95:32-39.

Mittler, R. 2002. Oxidative stress, antioxidants and stress tolerance. Trends Plant Sci. 7:405-410.

Mittler, R., A. Finka, and P. Goloubinoff. 2012. How do plants feel the heat? Trends Biochem. Sci. 37:118-125.

Onwueme, I.C. 1979. Rapid, plant-conserving estimation of heat tolerance in plants. J. Agr. Sci. 92:527-535.

Shen, H., B. Zhao, J. Xu, X. Zheng, and W. Huang. 2016. Effects of salicylic acid and calcium chloride on heat tolerance in rhododendron 'Fen Zhen Zhu'. J. Amer. Soc. Hort. Sci. 141:363-372.

Sivanandhan, G., M. Arun, S. Mayavan, M. Rajesh, T.S. Mariashibu, M. Manickavasagam, N. Selvaraj, and A. Ganapathi. 2012. Chitosan enhances withanolides production in adventitious root cultures of Withania somnifera (L.). Dunal. Ind. Crops Prod. 37:124-129.
Steinhorst, L. and J. Kudla. 2014. Signaling in cells and organisms - calcium holds the line. Curr. Opin. Plant Biol. 22:14-21.

Szymańska, R., I. Ślesak, A. Orzechowska, and J. Kruk. 2017. Physiological and biochemical responses to high light and temperature stress in plants. Environ. Expt. Bot. 139:165-177.

Tan, W., Q.W. Meng, M. Brestic, K. Olsovska, and X.H. Yang. 2011. Photosynthesis is improved by exogenous calcium in heat-stressed tobacco plants. J. Plant Physiol. 168:2063-2071.

Renu. and R. Srivastava. 2013. Effect of cycocel and alar on the growth and flowering of poinsettia cv. SINGLE. Asian J. Hort. 8:313-316.

Wu, M.T. and S.J. Waller. 1983. Heat stress responses in cultured plant cells: Developmen and comparison of viability test. Plant Physiol. 72:817-820.

Yang, S., F. Wang, F. Guo, J.J. Meng, X.G. Li, S.T. Dong, and S.B. Wan. 2013. Exogenous calcium alleviates photoinhibition of PSII by improving the xanthophyll cycle in peanut (Arachis hypogaea) leaves during heat stress under high irradiance. PLoS One 8:E71214. 


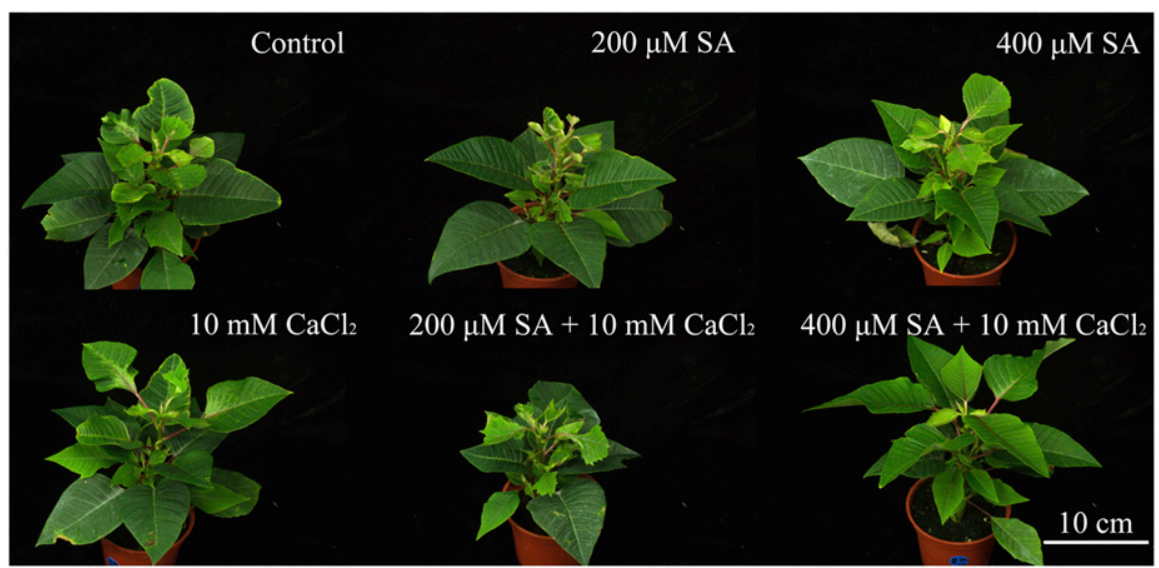

Supplemental Fig. 1. Effects of salicylic acid (SA) and calcium chloride $\left(\mathrm{CaCl}_{2}\right)$ treatments on the appearance of poinsettia 'Noel' under heat stress.

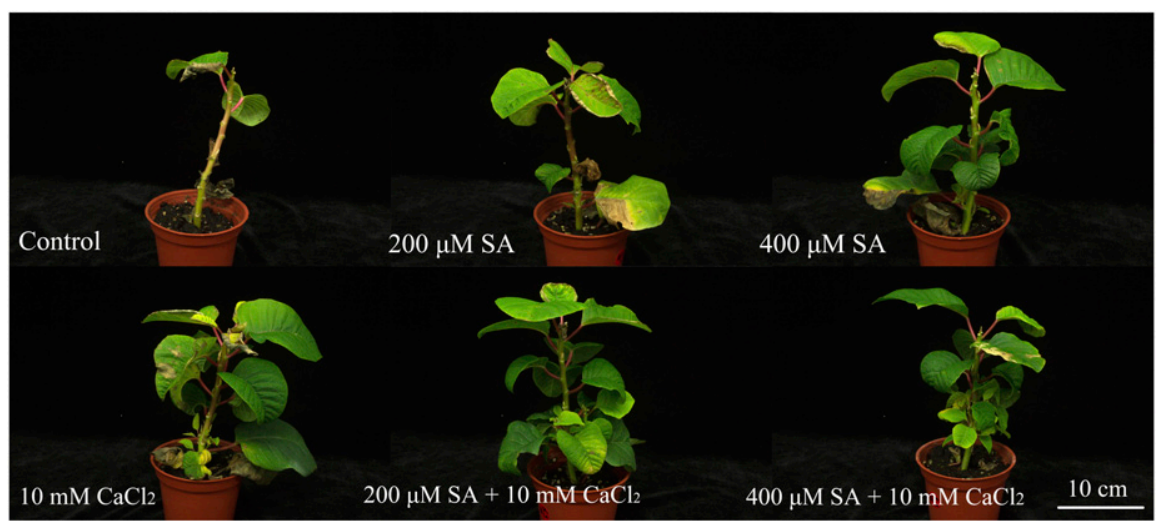

Supplemental Fig. 2. Effects of salicylic acid (SA) and calcium chloride $\left(\mathrm{CaCl}_{2}\right)$ treatments on the appearance of poinsettia 'Winter Rose' under heat stress.

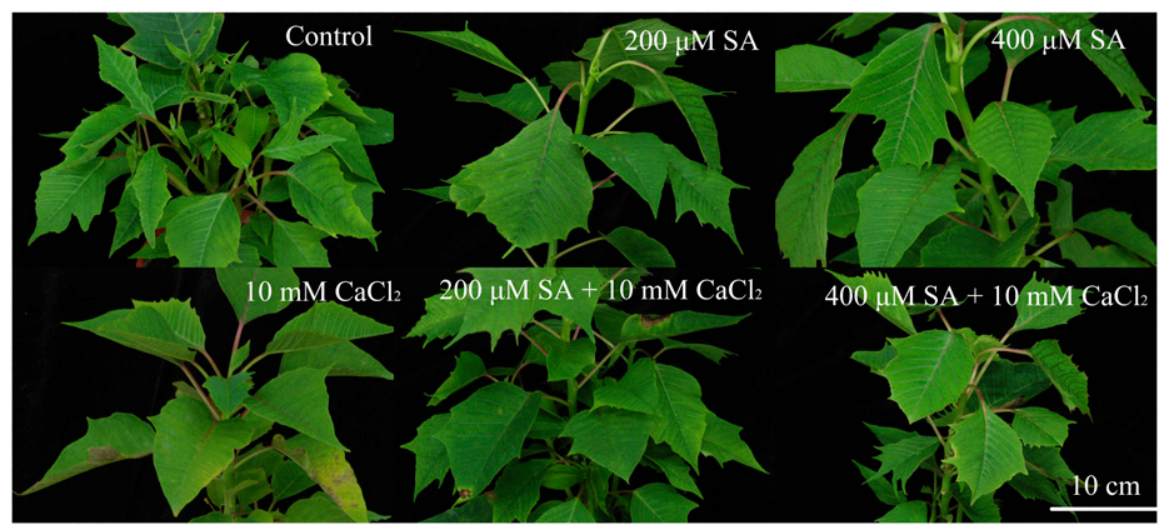

Supplemental Fig. 3. Effects of salicylic acid (SA) and calcium chloride $\left(\mathrm{CaCl}_{2}\right)$ treatments on the appearance of poinsettia 'Ice Punch' under heat stress. 